\title{
Modelling Sri Lankan Consumption Patterns Using Error Corrected LA-AIDS*
}

\author{
Shashika D. Rathnayaka ${ }^{1,2}$ Saroja Selvanathan ${ }^{1}$ E. A. Selvanathan ${ }^{1}$ and Parvinder Kler $^{1}$ \\ ${ }^{1}$ Griffith Business School, Griffith University, Queensland, Australia. \\ ${ }^{2}$ Department of Export Agriculture, Uva Wellassa University, Badulla, Sri Lanka.
}

\begin{abstract}
Static-demand systems used in empirical studies are based on the assumption that consumers immediately and fully adjust to a new equilibrium when either incomes or prices change. In reality, consumers are unlikely to have adjusted to equilibrium in each time period and the assumption of instantaneous adjustments by consumers is potentially incorrect. The dynamic modelling approach allows for intertemporal rationality of consumer behaviour by explicitly considering the mechanism underlying the short-run adjustment process. This study, while considering the traditional static Almost Ideal Demand System (AIDS), in addition, considers two dynamic versions of the AIDS to model the dynamic behaviour of Sri Lankan consumers in consuming eight broad commodity groups using data during the period 1963-2016. The estimated results indicate that all commodities have price inelastic demand in both the short and long run. The differences between short- and long-run demand elasticities indicate the need to adopt a dynamic approach in estimating demand elasticities, because the income and price elasticities are key inputs for policy analysis in economy-wide modelling.
\end{abstract}

Keywords: dynamic demand; error correction; demand theory hypotheses; demand elasticities

\footnotetext{
* The authors would like to thank the editor, associate editor and the anonymous reviewers of this journal for their constructive comments which has helped improve the paper significantly. The authors would also like to than the participants of the Australian Conference of Economists 2018, QT, Canberra, Australia, 10-13 July, 2018 , for their valuable comments on an initial version of this paper.
} 


\title{
Modelling Sri Lankan Consumption Patterns Using Error Corrected LA-AIDS*
}

\begin{abstract}
Static-demand systems used in empirical studies are based on the assumption that consumers immediately and fully adjust to a new equilibrium when either incomes or prices change. In reality, consumers are unlikely to have adjusted to equilibrium in each time period and the assumption of instantaneous adjustments by consumers is potentially incorrect. The dynamic modelling approach allows for intertemporal rationality of consumer behaviour by explicitly considering the mechanism underlying the short-run adjustment process. This study, while considering the traditional static Almost Ideal Demand System (AIDS), in addition, considers two dynamic versions of the AIDS to model the dynamic behaviour of Sri Lankan consumers in consuming eight broad commodity groups using data during the period 1963-2016. The estimated results indicate that all commodities have price inelastic demand in both the short and long run. The differences between short- and long-run demand elasticities indicate the need to adopt a dynamic approach in estimating demand elasticities, because the income and price elasticities are key inputs for policy analysis in economy-wide modelling.
\end{abstract}

Keywords: dynamic demand; error correction; demand theory hypotheses; demand elasticities 


\section{Introduction}

Economists have been studying the relationship between prices, income, and consumption for more than a century. Economic theories of consumer behaviour provide sophisticated mathematical descriptions of equilibrium relationships between demand and its determinants and, typically, is concerned with changes in the steady-state equilibrium caused by changes in demand determinants (De Mello 2001). Consequently, most empirical studies have used static demand systems for estimations. However, static demand systems ignore the many adjustments that occur in the short run (Hassan et al. 1977). In reality, consumers are unlikely to have adjusted to equilibrium in each time period and the assumption of instantaneous adjustments by consumers may be incorrect. Habit persistence, adjustment costs, incorrect expectations, and misinterpreted real price changes are among the many possible reasons for such short-run behaviour. Therefore, while waiting for full adjustments, consumers are potentially "out of equilibrium". While some policy decisions, such as introducing GST on consumer goods, are being implemented with a long-term view, there are other instances when decisions are being implemented with a short-term view, for example a producer wanting to market their product.

Static models are unlikely to provide reasonably maintained explanations of time series data. Application of static models to time series data leads to misspecification and relatively low explanatory power. This is due to the error term of each equation, which depends on its own past value and the past values of the errors of the demand equations of all other goods (Edgerton et al. 1996, Tridimas 2000). Hence, a more general structure for demand systems is required; one that allows for a test of the static model itself, as well as the theoretical restrictions and simplifications from demand theory (Anderson and Blundell 1983). Therefore, appropriate modelling of the dynamic adjustment of consumers' expenditure is essential before restrictions from demand theory are tested. 
The dynamic modelling approach allows for intertemporal rationality of consumer behaviour by explicitly considering the mechanism underlying the short-run adjustment process. The static demand model specifications ignore potential significant short-run elasticity measures that differ from the long-run estimates. Moreover, in the context of tax policy and business strategy, decision makers are more likely to be more concerned with short-run elasticity estimates and the speed to which these estimates reach their long-run level (Eakins and Gallangher 2003). For instance, the difference between short-run and long-run demand elasticities indicates that any policy affecting product prices and consumer income has a distinct impact in the short run and long run. In the context of businesses or producers, addressing dynamics of consumer behaviour and estimating short-run price elasticities are important, in order to see the impact of promotional pricing strategy, which is a short-term reduction in the product prices.

In this context, a number of recent studies in the area of consumption economics have recognised the importance of including dynamic adjustments in demand systems and have adopted a number of approaches. The conventional approach has been to include lagged values of selected variables, which exert important influence on current consumption. This approach assumes that consumers' reaction to changes in incomes and prices do not occur immediately but gradually. The origins of these lags are elucidated by Brown (1952), Houthakker and Taylor (1970), and Phillips (1983) as follows. First, consumers adjust slowly to changes in income and prices due to inertia in the face of these changes. This inertia is caused by memories of the prior levels of incomes and prices. Second, the lag effect in consumer demand is produced by consumption habits informed via past consumption. The habits, customs, and levels associated with previous consumption remain in consumers' memories and this affects current consumption. Though appropriate dynamic structure can be incorporated by expressing the dependent consumption variable as a function of the 
contemporaneous and lagged values of the independent variables, as well as lagged values of the dependent variables, choosing a suitable demand system to add the dynamic specifications is more complicated.

Of the many flexible demand systems available to describe long-run behaviour, given the complications of estimating demand models in a dynamic setting, the AIDS proposed by Deaton and Muellbauer (1980) is a particularly convenient choice. It is essentially linear in variables and does not assume homogeneity or symmetry, although it neatly allows the testing of these, as well as the homotheticity and homothetic separability restrictions (Anderson and Blundell 1983). The simplest way to introduce dynamics into the AIDS is to include the lagged budget share $w_{i, t-1}$ on the right-hand side of the AIDS equation. This has been performed by modifying the intercept term of the share equation, $\alpha_{i}$ (for example, Blanciforti and Green 1983, Blanciforti et al. 1986, Mergos and Donatos 1989, Karagiannis and Velentzas 1993, Molina 1994). These models incorporate both the effect of inventories and the influence of habits arising from past consumption on current demand. Unfortunately, such models do not satisfy adding up, unless we are willing to impose the additional restriction that the parameter of the lagged budget share is the same in all equations (Edgerton et al. 1996, Klonaris and Hallam 2003). A more general dynamic AIDS model that does not involve excessive over parameterisation was introduced by Alessie and Kapteyn (1991), Assarsson (1991), and Kesavan et al. (1993). In this new model, the $\propto_{i}$ parameter is related to not only its own past consumption level but also those of other items. Hence, it has become de rigueur among empirical consumption researchers (see Edgerton 1997, Shukur 2002, Klonaris and Hallam 2003, Mazzocchi, 2003).

Recent developments in time series analysis have opened an alternate route for introducing dynamics into demand systems. Anderson and Blundell (1983), Balcombe and Davis (1996), Edgerton et al. (1996), and Karagiannis and Velentzas (1997) have 
incorporated dynamic elements into the AIDS by relying on the statistical properties of the data. Anderson and Blundell (1983) developed a vector time series model of expenditure shares in the context of a singular dynamic demand system. Balcombe and Davis (1996) suggested the canonical cointegrating regression procedure for estimating the AIDS when the commodity prices follow a distributed lag process, or there is a seasonal pattern. Edgerton et al. (1996) and Karagiannis and Velentzas (1997) demonstrated the potential use of an error correction model (ECM) of the AIDS. They clearly show that as long as cointegration between the dependent and a linear combination of independent variables is guaranteed, an ECM for the AIDS can be established and econometrically estimated it with an iterative seemingly unrelated regression (ISUR) procedure.

This has led to the applications of the error corrected (EC) linear approximated (LA) AIDS (EC-LA-AIDS) in a number of recent studies of demand for nondurable goods, such as food and meat products. Using an EC-LA-AIDS, Karagiannis et al. (2000) analysed the meat demand in Greece; Eakins and Gallagher (2003) analysed the dynamics in alcohol expenditure in Ireland; Fanelli and Mozzocchi (2002) estimated demand for meat in Italy; and Nzuma and Sarker (2010) estimated demand for major cereals consumed in Kenya. Singh et al. (2011) employed an EC-LA-AIDS to estimate demand for major crustaceans at a disaggregated level in the United States. Also, a few studies have applied an EC-LA-AIDS to analyse tourism demand (for example, Durbarry and Sinclair 2003, Li et al. 2004, Wu et al. 2011, and Wu et al. 2012).

Though different forms of dynamic demand models have been used in the literature, a specification of the appropriate dynamic structure to represent the data is imperative. This is because inappropriate dynamic structures can lead to misspecifications that potentially yield unreliable estimates, invalid inference, and inaccurate forecasts, and, thus, wrong information for policy-makers (Anderson and Blundell 1983, De Mello and Fortuna 2005, Shukur 2002). 
In a departure from the bulk of the literature, in addition to the static LA-AIDS, this study considers two dynamic versions of the AIDS to model the dynamic behaviour of Sri Lankan consumers in consuming all consumer goods grouped into eight broad commodity groups, namely food, clothing, housing, durables, medical care, transport, and recreation. We then select the most preferred demand model using the goodness of fit measure-information inaccuracies and, then, calculate both the short- and long-run demand elasticities implied by the preferred demand system. Demand elasticities is a useful concept insofar as it describes how consumers react to change in prices and income. For example, they are essential inputs in computations of optimal taxation, tax reforms, and in applied computable general equilibrium models. To the best of our knowledge, there are no other published comprehensive econometric studies available that analyse the dynamic behaviour in Sri Lankan consumption patterns. Sri Lanka is a developing country in the Asia Pacific region, with a population of 22 million. Sri Lanka implemented liberalised trade policies during the 1970s and became a global trading partner. Accordingly, the study of Sri Lankan consumption patterns has become increasingly important, not only to the Sri Lankan government and its business community but also to its trading partners.

A minute number of investigations have analysed Sri Lankan consumer demand, with the bulk estimating single commodity nutrition specific demand equations specially aimed at food demand (see Sahn 1988, Nigel and Bogahawatte 1990, Pradhan and Thudawe 1997, Kottage 1988, Rathnayake et al. 2004, Weerahewa et al. 2013, Edirisinghe 2014, Lokuge and Edirisinghe 2015, Nirmali and Edirisinghe 2015). There also exist a few static cross-country consumption studies that included Sri Lankan consumption of broad commodity groups (for example, Deaton and Case 1987, Selvanathan and Selvanathan 2003, Clements et al. 2006). Nevertheless, these studies adopted static demand models where consumers were assumed to 
adjust instantly to the new equilibrium when incomes or prices change. This investigation, therefore, adds to the literature by bridging this gap.

The remainder of the paper is organised as follows. In Section 2, we present three versions of AIDS, namely the static LA-AIDS, dynamic LA-AIDS, and EC-LA-AIDS. In Section 3, we present the data, test for stationarity and cointegration, estimate three demand models, and test demand theory hypotheses. In Section 4, we select the preferred demand model using the goodness-of-fit measure to establish any information inaccuracy. In Section 5, we report the estimated short-run and long-run demand elasticities. In Section 6, we present the concluding comments.

\section{Demand models for estimation}

In this section, we discuss the three different versions of AIDS, which will be estimated in Section 3.

\section{Static LA-AIDS}

The AIDS developed by Deaton and Muellbauer (1980) has been the model of choice for many applied demand analysts for almost three decades. The reason for the popularity of this particular demand system is due to its strong theoretical underpinning, well-structured analytical framework, ability to accommodate certain types of aggregation, and its ease-ofestimation, which also permits testing of the standard classical demand theory hypotheses (Buse 1994, Wu et al. 2012).

The standard AIDS in budget share form can be written as:

$$
w_{i}=\alpha_{i}+\beta_{i} \log \frac{M}{P}+\sum_{j=1}^{n} \gamma_{i j} \log p_{j} \quad i=1,2, \ldots, n
$$


where $w_{i}$ is the budget-share of the $i^{\text {th }}$ commodity, $p_{j}$ is the price of $j^{\text {th }}$ commodity, $M=\sum_{i=1}^{n} p_{i} q_{i}$ is the total expenditure on all commodities and $P$ is an aggregate price index defined as:

$$
\log P=\sum_{k=1}^{n} \alpha_{k} \log p_{k}+\frac{1}{2} \sum_{k=1}^{n} \sum_{j=1}^{n} \gamma_{k j} \log p_{k} \log p_{j}
$$

Adding up condition requires that

$$
\sum \alpha_{i}=1, \sum \beta_{i}=0, \sum_{i=1}^{n} \gamma_{i j}=0
$$

and homogeneity hold if $\sum_{j=1}^{n} \gamma_{i j}=0$ and the symmetry conditions require that $\gamma_{i j}=\gamma_{j i}$, $i=j=1,2, \ldots n$.

One drawback in estimating the AIDS is that the price index is non-linear in the parameters, resulting in some empirical difficulties in estimation, in particular when we use aggregate annual time series data. To overcome these issues, Deaton and Muellbauer (1980) proposed an appropriately specified price index that can be defined outside of the AIDS system, to replace the above non-linear price index. This price index is the well-known Stone's share-weighted geometric mean price index.

$$
\log P=\sum_{k=1}^{n} w_{k} \log p_{k}
$$

Equation (1) with $\log P$ replaced by Stone's price index is known as the LA-AIDS, which has been extensively used in the literature. As shown by Asche and Wesslls (1997), the AIDS and the LA-AIDS representations are identical at the point of approximation, as long as the prices in the system are normalised to one.

Income and price elasticities implied by the LA-AIDS as follows:

$$
\eta_{i}=1+\frac{\beta_{i}}{w_{i}}, \quad \quad \quad=\quad 1, \ldots, n
$$


and

$$
\eta_{i j}=-\delta_{i j}+\frac{\gamma_{i j}}{w_{i}}-\frac{\beta_{i} w_{j}}{w_{i}}
$$

$$
i, \quad j \quad=\quad 1, \ldots, n
$$

\section{Dynamic LA-AIDS}

Several authors have addressed the problem of developing a dynamic version of the AIDS. Two crucial problems concerning consistency with economic theory appear in their work. First, the dynamic system should be derived from a proper expenditure function and, second, the adding-up property should be satisfied (Edgerton et al 1996).

Blanciforti and Green (1983) operationalised a dynamic AIDS by incorporating habit effects in the spirit of Pollak and Wales (1969), positing the specification below:

$$
\alpha_{i}=\alpha_{i}^{*}+\alpha_{i}^{* *} q_{i t-1}
$$

However, this does not meet the adding-up requirement. Ray (1984) suggested a method to simply add the term $\sum_{j} \alpha_{j}^{* *} q_{j t-1}$ to the expenditure function. This will only change the form of the price index, however. Alessie and Kapteyn (1991), Assasson (1991) and Kesavan et al. (1993) proposed the following specification to get a more general dynamic AIDS model, which does not involve excessive over parameterisation.

$$
\alpha_{i}=\alpha_{i}^{*}+\sum_{j} \theta_{i j}{ }^{w} j t-1
$$

Substitution of equation (5) in equation (1) will result in the following dynamic version of AIDS as

$$
w_{i t}=\alpha_{i}^{*}+\sum_{j=1}^{n} \theta_{i j} w_{j t-1}+\beta_{i} \log \frac{M}{P}+\sum_{j=1}^{n} \gamma_{i j} \log p_{j}
$$


where, in addition, we impose $\sum \alpha_{i}^{*}=1$ and $\sum_{j} \theta_{i j}=0$ for identification and $\sum_{i} \theta_{i j}=0$ for adding up.

\section{Error Corrected LA-AIDS}

Because we use time series data to estimate the demand system, it is appropriate to first investigate whether the time series variables used for estimation are non-stationary. Moreover, before specifying the appropriate dynamic version of the AIDS, it is necessary, exante, to investigate the time series properties of the data, in order to formally assess whether the long-run demand relationships are economically meaningful or spurious (Karagiannis et al. 2000, Nzuma and Sarker 2010). Initially, all relevant variables are tested for unit root (or order of integration). A number of empirical tests available in the literature can be employed for this purpose; the most frequently used tests being the augmented Dickey and Fuller (ADF) (1979) test and the Phillips and Perron (PP) (1988) test.

Once the order of integration of the variables has been identified, the system is tested for cointegration. This can be implemented using either the ADF and PP tests or the Johansen's maximum likelihood cointegration analysis. However, a major limitation of Johansen's approach in the case of applied demand analysis is that there is no a priori information to exclude some vectors as theoretically inconsistent whenever more than one cointegrated vectors are found (Karangiannis et al. 2000, Nzuma and Sarker 2010).

When the variables in equation (1) are I(1) and cointegrated, an EC-LA-AIDS can be specified as follows:

$$
\Delta w_{i t}=\alpha_{i}+\theta_{i} \Delta w_{i t-1}+\beta_{i} \Delta \ln \left(\frac{M_{t}}{P_{t}}\right)+\sum_{j=1}^{n} \gamma_{i j} \Delta \ln p_{j t}+\lambda_{i} \mu_{i t-1}+\varepsilon_{i t}
$$


where $\Delta$ is the difference operator and $\mu_{i t-1}$ is the error correction term that measures the adjustment of the decision errors made in the previous period, which is estimated using the residual term from the long-run static AIDS model in equation (1). We have incorporated habit effects into equation (7) by including the lagged dependent variable. This is to indicate that consumption patterns of last year would affect current budget allocation decisions. This formulation is similar to that used by Karagiannis et al. (2000), Li et al. (2004) and Nzuma and Sarker (2010). The coefficient $\lambda_{i}$ is expected to be negative; it represents the adjustment of equation (1) in response to the disequilibrium of the budget allocation related to commodity $i$ at time $t-1$. However, the adding-up condition requires $\theta_{i}$ and $\lambda_{i}$ to be constants with respect to $i$ and equal in each equation in the system, as suggested by Edgerton et al (1996, p. 197).

\section{Estimation of the demand models}

Below we present details on the data sources, estimate the model, discuss the estimation results, and present the results of testing demand theory hypotheses.

\section{The data}

The basic data used in this study is the annual consumption expenditures in current and constant prices of goods and services and the population of Sri Lanka for the period 1963$2016(N=54)$. Data for the period 1963-1995 was drawn from various issues of the United Nations - Yearbook of National Accounts Statistics, while 1996-2016 data was taken from the United Nations database and various issues of the Central Bank of Sri Lanka publications. Sri Lankan population data for the years 1963-2016 was also obtained from the United Nations database. Goods and services are classified into $(n=8)$ broad commodity groups and Table 1 presents their detailed description. 
The budget shares, sample mean, sample standard deviation, and sample coefficient of variation for the eight commodity groups for selected years are presented in Table 2 . Expenditure on food claims the largest share of total consumption expenditure, despite displaying a sharp downward trend. On the other hand, expenditures on housing and transport exhibit greater relative importance throughout the period. On average, Sri Lankan consumers spend more than half of their income on food and nearly 80 percent of their income on food, 
Table 1 Classification of commodities.

\begin{tabular}{ll}
\hline Commodity Group & Description \\
\hline 1. Food & Food, Non-alcoholic and Alcoholic beverages \\
2. Clothing & Clothing and Footwear \\
3. Housing & Rent, Fuel and Power \\
4. Durables & Furniture, Furnishings, Household equipment and operation \\
5. Medical care & Medical care and Health expenses \\
6. Transport & Personal transport equipment and Communications \\
7. Recreation & Educational, Recreational, Entertainment and Cultural services \\
8. Miscellaneous & Personal care, Expenditure in restaurants, Cafes and Hotels and Other \\
\hline
\end{tabular}

Table 2 Budget shares of eight broad commodity groups (in percentages), Sri Lanka, 19632016.

\begin{tabular}{lccccccccc}
\hline Coomodity & 1963 & 1985 & 2000 & 2016 & Period mean & Minimum & Maximum & $\begin{array}{c}\text { Standard } \\
\text { deviation }\end{array}$ & $\begin{array}{c}\text { Coefficient } \\
\text { of variation }\end{array}$ \\
$(1)$ & $(2)$ & $(3)$ & $(4)$ & $(5)$ & $(6)$ & $(7)$ & $(8)$ & $(9)$ & $(10)$ \\
\hline Food & 66.90 & 56.42 & 51.42 & 40.99 & 56.22 & 38.64 & 71.39 & 9.79 & 17.41 \\
Clothing & 6.62 & 7.07 & 9.35 & 4.68 & 7.03 & 4.68 & 9.90 & 1.19 & 16.97 \\
Housing & 7.30 & 5.90 & 7.30 & 15.38 & 7.80 & 3.94 & 15.38 & 3.38 & 43.35 \\
Durables & 4.20 & 4.67 & 4.54 & 4.31 & 4.68 & 3.16 & 6.95 & 0.82 & 17.62 \\
Medical care & 2.70 & 1.61 & 1.60 & 2.02 & 1.94 & 1.23 & 3.77 & 0.59 & 30.12 \\
Transport & 5.48 & 16.45 & 17.12 & 25.54 & 14.73 & 5.48 & 26.94 & 6.81 & 46.21 \\
Recreation & 5.81 & 4.83 & 3.14 & 2.78 & 4.01 & 2.49 & 6.89 & 1.21 & 30.10 \\
Miscellaneous & 0.99 & 3.06 & 5.54 & 4.30 & 3.58 & 0.95 & 5.56 & 1.20 & 33.46 \\
\hline
\end{tabular}

housing, and transport combined. This observation is in line with that observed for most of the other developing countries (for example, see Chen 2001 and Selvanathan and Selvanathan 2006). The CV values presented in the last column of Table 2 indicate that transport has the highest variation (46.21 percent) in budget share followed by housing (43.35 percent) and then medical care and recreation about equally (30 percent). The variation in budget share is lower for clothing (16.97 percent) compared to all other commodities.

\section{Testing for stationarity and cointegration}

As aforementioned, the estimation of the relevant econometric model needs to be initiated by investigating the time series properties of the data. This research utilises the ADF unit root 
test to determine the presence of unit root and the test results are presented in Table 3. As can be 
Table 3 ADF test results for commodity prices and total expenditure.

\begin{tabular}{|c|c|c|c|c|c|}
\hline \multirow{2}{*}{ Series } & \multicolumn{2}{|l|}{ Level series } & \multicolumn{2}{|l|}{ First differences } & \multirow{3}{*}{$\begin{array}{c}\mathrm{I}(\mathrm{d}) \\
(6)\end{array}$} \\
\hline & Test Statistics & $\mathrm{p}$-value & Test Statistics & $\mathrm{p}$-value & \\
\hline$(1)$ & (2) & (3) & (4) & (5) & \\
\hline \multicolumn{6}{|l|}{ Budget shares (w) } \\
\hline w food & -0.347 & 0.919 & -6.739 & 0.000 & $I(1)$ \\
\hline w clothing & -2.131 & 0.232 & -8.968 & 0.000 & $I(1)$ \\
\hline w housing & 0.360 & 0.980 & -6.998 & 0.000 & $I(1)$ \\
\hline w durables & -2.426 & 0.135 & -5.966 & 0.000 & $I(1)$ \\
\hline w medical care & -2.404 & 0.141 & -6.655 & 0.000 & $I(1)$ \\
\hline w transport & -0.333 & 0.921 & -7.169 & 0.000 & $I(1)$ \\
\hline w recreation & -2.577 & 0.098 & -8.027 & 0.000 & $I(1)$ \\
\hline w miscellaneous & -2.949 & $0.040^{*}$ & -9.710 & 0.000 & $I(1)^{*}$ \\
\hline \multicolumn{6}{|c|}{ Logarithm of commodity prices $(\log p)$} \\
\hline Log $p$ food & -0.330 & 0.921 & -5.214 & 0.000 & $I(1)$ \\
\hline Log $p$ clothing & 0.260 & 0.975 & -7.646 & 0.000 & $I(1)$ \\
\hline Log $p$ housing & -0.263 & 0.931 & -4.657 & 0.002 & $I(1)$ \\
\hline Log $p$ durables & -0.226 & 0.935 & -7.513 & 0.000 & $I(1)$ \\
\hline Log $p$ medical care & -0.479 & 0.896 & -6.931 & 0.000 & $I(1)$ \\
\hline Log $p$ transport & -0.469 & 0.898 & -6.870 & 0.000 & $I(1)$ \\
\hline Log $p$ recreation & -0.875 & 0.796 & -11.541 & 0.000 & $I(1)$ \\
\hline Log $p$ miscellaneous & -0.542 & 0.884 & -7.299 & 0.000 & $I(1)$ \\
\hline Log of total expenditure(M) & 0.935 & 0.994 & -5.125 & 0.000 & $I(1)$ \\
\hline$\underline{\log (\mathrm{M} / \mathrm{P})}$ & 1.682 & 0.998 & -6.255 & 0.000 & $I(1)$ \\
\hline
\end{tabular}

*significant at $1 \%$ level.

seen, the hypothesis that all the variables in equation (1) contain a unit root cannot be rejected at the $5 \%$ level of significance. However, when each series is first differenced, the unit root (non-stationarity) hypothesis was rejected at the same level of significance. This suggests that all the variables used in this study (in level form) are non-stationary, integrated of order one, I(1). Next, we carry out the cointegration test to investigate whether the budget shares are jointly determined by income and their respective prices. The concept of cointegration (CI), first proposed by Engle and Granger (1987), states that a linear combination of non-stationary variables may be stationary. This means that two variables will be cointegrated if they have a long-term or equilibrium relationship. In this study, we used two residual based tests (Dickey-Fuller cointegration test and Phillips-Perron cointegration test) to test for this. Table 4 presents the results. As can be seen, both tests reject the hypothesis of no cointegration for 
budget shares for all the commodities. Cointegration ensures that shocks affecting commodity prices or real expenditures will be reflected in different budget shares in a similar way. This indicates that these variables are moving together in the long run and obey an equilibrium constraint.

Table 4 Results of cointegration test.

\begin{tabular}{|c|c|c|c|c|}
\hline \multirow{2}{*}{$\begin{array}{l}\text { Series } \\
(1) \\
\end{array}$} & \multicolumn{2}{|c|}{$\underline{\text { Dickey-Fuller cointegration test }}$} & \multicolumn{2}{|c|}{ Phillips-Perron cointegration test } \\
\hline & $\begin{array}{c}\text { Test Statistics } \\
(2) \\
\end{array}$ & $\begin{array}{c}\mathrm{p} \text {-value } \\
(3)\end{array}$ & $\begin{array}{c}\text { Test Statistics } \\
\text { (4) }\end{array}$ & $\begin{array}{c}\mathrm{p} \text {-value } \\
(5)\end{array}$ \\
\hline \multicolumn{5}{|c|}{ Budget shares (w) } \\
\hline w food & -5.272 & 0.000 & -5.179 & 0.000 \\
\hline w clothing & -5.742 & 0.000 & -5.949 & 0.000 \\
\hline w housing & -4.442 & 0.000 & -4.404 & 0.000 \\
\hline w durables & -3.911 & 0.002 & -3.993 & 0.001 \\
\hline w medical care & -4.321 & 0.000 & -4.294 & 0.001 \\
\hline w transport & -5.797 & 0.000 & -5.727 & 0.000 \\
\hline w recreation & -5.328 & 0.000 & -5.319 & 0.000 \\
\hline w miscellaneous & -5.528 & 0.000 & -5.399 & 0.000 \\
\hline
\end{tabular}

\section{Testing for demand theory hypotheses}

We now estimate the static LA-AIDS given in equation (1), dynamic form of LA-AIDS given in equation (6), and the EC-LA-AIDS given in equation (7). We use the seemingly unrelated regression (SUR) procedure available in STATA 13.1. Because the sum of all expenditure shares in both equations (1) and (6) is equal to unity, the residuals variance-covariance matrix is singular. The usual solution is to delete one of the equations from the system and estimate the remaining $(n-1)$ equations. In this study, we dropped the equation for 'miscellaneous' and then calculated the parameters in the deleted equation in accordance with the adding-up restrictions. Since SUR is sensitive to the dropped equation, the procedure should be iterated, as in most empirical demand studies. According to Judge et al. (1980), the process of iteration ensures that the obtained estimates asymptotically approach those of the maximum likelihood method. 
Because there is a long-run cointegrating relationship among the variables, we estimate the EC-LA-AIDS specified in equation (7) using the two-step method of Engle and Granger (1987), where the estimated residuals of equation (1) are used as a regressor that represents the EC term in equation (7).

Initially we estimate the three demand systems in their unrestricted form and test the demand theory hypotheses of homogeneity and symmetry. The conventional methods to test the homogeneity and symmetry, and the joint test for both homogeneity and symmetry, are based on the Wald test, the likelihood ratio test, and the Lagrange multiplier test. However, simulation experiments have shown that these tests have considerable bias towards rejecting the null hypothesis, especially when they are applied to large demand systems with relatively few observations (Laitinen 1978, Meinser 1979, Bera, Byron and Jarque 1981, Selvanathan 1993, Selvanathan and Clements 1995, Balcombe and Davis 1996). To avoid this, we use the sample size-corrected statistic developed by Court (1968) and Deaton (1974) to test the homogeneity, symmetry, and homogeneity and symmetry. The test statistic is calculated as follows (see Court 1968 and Deaton 1974):

$$
T=\frac{\operatorname{tr}\left(\Omega^{R}\right)^{-1}\left(\Omega^{R}-\Omega^{U}\right) / q}{\operatorname{tr}\left(\Omega^{R}\right)^{-1} \Omega^{U} /(n-1)(N-k)}
$$

where $\Omega^{R}$ and $\Omega^{U}$ denote the estimated residual covariance matrices with and without restrictions imposed, respectively, $N$ is the number of observations, $n$ is the number of equations in the system, $k$ is the number of estimated parameters in each equation, and $\mathrm{q}$ is the number of restrictions. The test statistic $T$ is approximately distributed as $F(q, N-k)$. This test statistic has been used in several empirical studies in the literature (see Baldwin, Hadid, and Phillips 1983, Chambers 1990, Li et al. 2004, Wu et al. 2012).

Demand theory hypotheses test results are given in Table 5. The dynamic LA-AIDS and EC-LA-AIDS pass all three tests at the 5\% level of significance. However, the static LA- 
AIDS fails all three hypotheses at the $5 \%$ significance level but homogeneity and symmetry individually are accepted at the $1 \%$ level.

Table 5 Homogeneity and symmetry restriction tests.

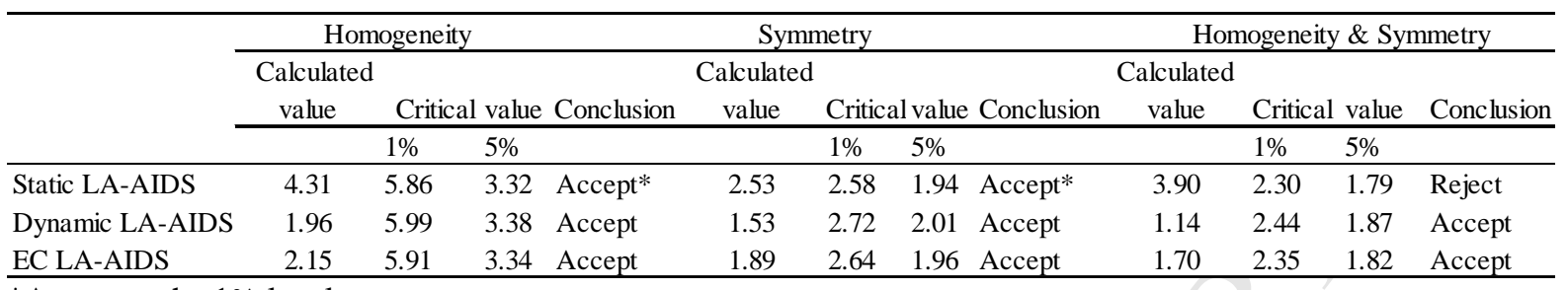

*Accept at the $1 \%$ level.

\section{The preferred demand model}

In this section, we use the goodness-of-fit measure, information inaccuracy, to select the preferred demand system by calculating information inaccuracy for each commodity and for the whole model.

Let $w_{1 t}, \ldots, w_{n t}$ be the observed budget shares of $n$ commodities in period $\mathrm{t}$, and $\widehat{w}_{1 t}$ ,..., $\widehat{w}_{n t}$ be the predicted budget shares implied by the demand model. The information inaccuracies for the predictions by commodity $i$ is given by (for example, see Theil, 1975):

$$
I_{i t}=w_{i t} \ln \left(\frac{w_{i t}}{\hat{w}_{i t}}\right)+\left(1-w_{i t}\right) \ln \left(\frac{1-w_{i t}}{1-\hat{w}_{i t}}\right)
$$

and the overall information inaccuracy for the whole model predictions is given by:

$$
I_{t}=\sum_{i=1}^{n} w_{i t} \ln \left(\frac{w_{i t}}{\hat{w}_{i t}}\right)
$$

The information inaccuracies measure the extent to which the predicted budget shares $\widehat{w}_{i t}$ differ from the corresponding observed budget shares $w_{i t}$. Both $I_{i t}$ and $I_{t}$ are non-negative 
and the larger their observed value, the poorer is the quality of the predicted budget shares $\widehat{w}_{1 t}, \ldots, \widehat{w}_{n t}$.

Table 6 presents the mean information inaccuracies for each commodity and the last row of the table for each model as a whole. As can be seen, at the individual commodity level, looking at the best-fit column, EC-LA-AIDS performs better than static LA-AIDS and dynamic LA-AIDS. Therefore, based on the goodness-of-fit measure, information inaccuracy, we conclude that the preferred model for modelling dynamic consumer behaviour of Sri Lankans is EC-LA-AIDS.

Table 6 Information inaccuracies $I_{i t}$ and $I_{t}\left(\times 10^{2}\right)$.

\begin{tabular}{lcccl}
\hline Commodity & \multicolumn{3}{c}{ Demand Model } & Best-fit \\
\cline { 2 - 4 } & Static LA-AIDS & $\begin{array}{c}\text { Dynamic } \\
\text { LA-AIDS }\end{array}$ & EC LA-AIDS & \\
\hline Food & 727.32 & 776.56 & 561.25 & EC LA-AIDS \\
Clothing & 549.30 & 367.98 & 307.95 & EC LA-AIDS \\
Housing & 661.98 & 347.63 & 394.04 & Dynamic LA-AIDS \\
Durables & 350.92 & 203.99 & 208.07 & Dynamic LA-AIDS \\
Medical care & 289.93 & 141.30 & 160.94 & Dynamic LA-AIDS \\
Transport & 355.59 & 369.69 & 308.49 & EC LA-AIDS \\
Recreation & 566.58 & 526.21 & 456.42 & EC LA-AIDS \\
Miscellaneous & 681.59 & 658.20 & 554.45 & EC LA-AIDS \\
Total $\left(I_{t}\right)$ & 4183.22 & 3391.56 & 3001.59 & EC LA-AIDS \\
\hline
\end{tabular}

\section{Estimation results and demand elasticities}

Table 7 presents the estimated results for the preferred demand system, EC-LA-AIDS, under homogeneity and symmetry. As can be seen from the table, the majority of the estimated free parameter estimates are statistically significant. The estimated parameter $\theta$ is significant, indicating that habit persistance plays an important role in Sri Lankan consumers' decisionmaking process. The error correction coefficient $\lambda$ is significantly negative, as expected, indicating that any deviations from the long-run equilibrium are corrected to bring the system back toward the equilibrium path. The estimated income coefficients $\left(\beta_{i}\right)$ are negative for food and durables, which indicates that these goods are necessities for Sri Lankan consumers, 
while the estimated income coefficients $\left(\beta_{i}\right)$ are positive for clothing, housing, medical care, transport, and recreation, which indicates that they are considered luxuries.

Table 7 Parameter estimates of EC-LA-AIDS for eight broad commodity groups, Sri Lanka, 1963-2016.

\begin{tabular}{|c|c|c|c|c|c|c|c|c|}
\hline \multirow[t]{2}{*}{ Parameter } & \multicolumn{8}{|c|}{ Estimated Parameters } \\
\hline & Food & Clothing & Housing & Durables & Medical care & Transport & Recreation & Miscellaneous \\
\hline \multirow[t]{2}{*}{$\gamma_{\mathrm{i} 1}$} & 0.080 & -0.020 & -0.021 & -0.016 & -0.015 & -0.008 & -0.002 & 0.002 \\
\hline & $(2.65)$ & $(-1.81)$ & $(-1.65)$ & $(-2.08)$ & $(-2.90)$ & $(-0.60)$ & $(-0.21)$ & $(0.21)$ \\
\hline \multirow[t]{2}{*}{$\gamma_{\mathrm{i} 2}$} & -0.020 & 0.012 & 0.000 & 0.003 & 0.000 & 0.002 & -0.001 & 0.005 \\
\hline & $(-1.81)$ & $(1.42)$ & $(0.03)$ & $(0.64)$ & $(-0.03)$ & $(0.22)$ & $(-0.30)$ & $(0.93)$ \\
\hline \multirow[t]{2}{*}{$\gamma_{\mathrm{i} 3}$} & -0.021 & 0.000 & 0.021 & 0.024 & -0.001 & -0.019 & 0.000 & -0.004 \\
\hline & $(-1.65)$ & $(0.03)$ & $(2.05)$ & (4.44) & $(-0.26)$ & $(-2.46)$ & $(0.08)$ & $(-0.82)$ \\
\hline \multirow[t]{2}{*}{$\gamma_{\mathrm{i} 4}$} & -0.016 & 0.003 & 0.024 & 0.002 & 0.006 & -0.013 & -0.002 & -0.004 \\
\hline & $(-2.08)$ & $(0.64)$ & $(4.44)$ & $(0.28)$ & (1.67) & $(-2.34)$ & $(-0.46)$ & $(-0.87)$ \\
\hline \multirow[t]{2}{*}{$\gamma_{\mathrm{i} 5}$} & -0.015 & 0.000 & -0.001 & 0.006 & 0.000 & -0.005 & 0.010 & 0.005 \\
\hline & $(-2.90)$ & $(-0.03)$ & $(-0.26)$ & (1.67) & $(-0.10)$ & $(-1.44)$ & (4.67) & (1.82) \\
\hline \multirow[t]{2}{*}{$\gamma_{\mathrm{i} 6}$} & -0.008 & 0.002 & -0.019 & -0.013 & -0.005 & 0.060 & -0.010 & -0.007 \\
\hline & $(-0.60)$ & $(0.22)$ & $(-2.46)$ & $(-2.34)$ & $(-1.44)$ & (5.34) & $(-1.75)$ & $(-1.25)$ \\
\hline \multirow[t]{2}{*}{$\gamma_{\mathrm{i} 7}$} & -0.002 & -0.001 & 0.000 & -0.002 & 0.010 & -0.010 & 0.009 & -0.005 \\
\hline & $(-0.21)$ & $(-0.30)$ & $(0.08)$ & $(-0.46)$ & (4.67) & $(-1.75)$ & $(1.65)$ & $(-1.22)$ \\
\hline \multirow[t]{2}{*}{$\gamma_{\mathrm{i} 8}$} & 0.002 & 0.005 & -0.004 & -0.004 & 0.005 & -0.007 & -0.005 & 0.008 \\
\hline & $(0.21)$ & (0.93) & $(-0.82)$ & $(-0.87)$ & (1.82) & $(-1.25)$ & $(-1.22)$ & (1.30) \\
\hline \multirow[t]{2}{*}{$\beta_{\mathrm{i}}$} & -0.100 & 0.013 & 0.060 & -0.015 & 0.000 & 0.032 & 0.004 & 0.006 \\
\hline & $(-2.66)$ & (0.89) & (3.68) & $(-1.47)$ & $(0.05)$ & (1.57) & $(0.26)$ & $(-0.42)$ \\
\hline \multirow{2}{*}{$\bar{\theta}_{i}$} & 0.142 & 0.142 & 0.142 & 0.142 & 0.142 & 0.142 & 0.142 & 0.142 \\
\hline & $(3.10)$ & (3.10) & (3.10) & $(3.10)$ & (3.10) & $(3.10)$ & (3.10) & (3.10) \\
\hline \multirow[t]{2}{*}{$\lambda_{i}$} & -0.632 & -0.632 & -0.632 & -0.632 & -0.632 & -0.632 & -0.632 & -0.632 \\
\hline & $(-12.23)$ & $(-12.23)$ & $(-12.23)$ & $(-12.23)$ & $(-12.23)$ & $(-12.23)$ & $(-12.23)$ & $(-12.23)$ \\
\hline
\end{tabular}

Note: $t$ statistics are in parentheses.

We now calculate both the short- and long-run income and price elasticities based on equations (2) and (3) and the estimates obtained from estimating equation (1) (long-run) and equation (7) (short-run). Short-run parameter estimates are presented in Table 7. The longrun estimates are not presented here but are available on request from the authors. The implied short-run and long-run elasticity estimates are presented in Table 8. The estimated expenditure elasticities in both the short run and long run, reported in columns (2) and (3) of the table, are uniformly positive. In both time horizons, housing, medical care, transport, and recreation are found to have expenditure elasticities greater than one, which indicates that 
these commodities are luxuries for Sri Lankan consumers. However, clothing is a luxury in the short run while a necessity in the long run. Food and durables are necessities in both time frames. Given the magnitude of short- and long-run expenditure elasticities, demand for housing, medical care, transport, and recreation are more responsive to income changes in the long run than in the short run.

Table 8 Demand elasticities for eight broad commodity groups, Sri Lanka, 1963-2016.

\begin{tabular}{lccccc}
\hline Commodity & \multicolumn{2}{c}{ Expenditure elasticities } & & \multicolumn{2}{c}{ Own-price elasticities } \\
\cline { 2 - 3 } \cline { 5 - 6 }$(1)$ & Short-run & Long-run & & Short-run & Long-run \\
Food & $(2)$ & $(3)$ & & $(4)$ & $(5)$ \\
Clothing & 0.822 & 0.634 & & -0.758 & -0.673 \\
& $(0.067)$ & $(0.036)$ & & $(0.091)$ & $(0.079)$ \\
Housing & 1.188 & 0.858 & & -0.845 & -0.657 \\
& $(0.210)$ & $(0.133)$ & & $(0.133)$ & $(0.233)$ \\
Durables & 1.773 & 2.846 & & -0.792 & -0.885 \\
& $(0.210)$ & $(0.123)$ & & $(0.147)$ & $(0.166)$ \\
Medical care & 0.682 & 0.616 & & -0.951 & -0.645 \\
& $(0.217)$ & $(0.132)$ & & $(0.134)$ & $(0.178)$ \\
Transport & 1.015 & 1.787 & & -1.018 & -0.991 \\
& $(0.313)$ & $(0.191)$ & & $(0.185)$ & $(0.223)$ \\
Recreation & 1.214 & 1.403 & & -0.623 & -0.735 \\
& $(0.136)$ & $(0.065)$ & & $(0.097)$ & $(0.123)$ \\
Miscellaneous & 1.098 & 1.399 & & -0.786 & -0.730 \\
& $(0.370)$ & $(0.184)$ & & $(0.147)$ & $(0.162)$ \\
& 1.161 & 0.975 & -0.786 & -0.613 \\
& $(0.388)$ & $(0.192)$ & $(0.183)$ & $(0.268)$ \\
\hline
\end{tabular}

Note: Standard errors are in parentheses.

Considering the own-price elasticities presented in columns (4) and (5) of Table 8, we can see that short- and long-run, own-price elasticities for all commodities are negative and less than one in absolute value (except medical care in the short run). This indicates that all the commodities have price inelastic demand at all time periods. Short-run, own price elasticities in absolute value are smaller than their long-run counterparts for housing and transport.

\section{Concluding Comments}


This paper modelled the dynamic behaviour of Sri Lankan consumption patterns using annual time series data for the period 1963-2016 for eight commodity groups using a static and two dynamic versions of AIDS, namely LA-AIDS, dynamic LA-AIDS, and EC-LA-AIDS.

The study estimated the three demand models and tested the demand theory hypotheses, homogeneity, and symmetry. Results suggest that both dynamic LA-AIDs and EC-LA-AIDS satisfy the demand theory hypotheses better than static LA-AIDS. Based on the goodness-offit measure, information inaccuracy, we found that the EC-LA-AIDS models perform better than the static LA-AIDS and dynamic LA-AIDS.

Both the short- and long-run implied own-price elasticities for all commodities are negative, and all the commodities have price inelastic demand in both time horizons (except medical care in the short run). Housing, medical care, transport, and recreation are found to be luxuries for Sri Lankan consumers, both in the short and long run. However, clothing is a necessity in the long run, while it is a luxury in the short run. As far as the magnitude of short- and long-run demand elasticities are concerned, Sri Lankan consumers are more sensitive to price and income changes in the long run than in the short run in consuming some of the commodities. The deviation between both time periods demand elasticities shows the need for adopting a dynamic approach in estimating demand elasticities where these are to be used for policy and welfare analyses.

This study has identified the appropriate dynamic structure to represent the data while investigating the empirical validity of the constraints of homogeneity and symmetry. Therefore, the current study has been able to provide new insight into the analysis of Sri Lankan consumption patterns while providing more reliable information for policy evaluation than the static demand models. The income and price elasticities obtained from this study can be used as key inputs in computations of optimal taxation, tax reforms and in applied computable general equilibrium models. 


\section{References}

Anderson, G., and Blundell, R. (1983). "Testing restrictions in a flexible dynamic demand system: an application to consumers' expenditure in Canada". The Review of Economic Studies, 50(3): 397-410.

Assarson, B. (1991). "Alcoholic pricing policy and the demand for Alcohol in Sweden 19781988”. Working Paper, Department of Economics, Uppsala University, Sweden.

Alessie, R., and Kapteyn, A. (1991). "Habit formation, interdependent preferences and demographic effects in the almost ideal demand system". The Economic Journal, 101(406): 404-419.

Asche, F., and Wessells, C. R. (1997). "On price indices in the almost ideal demand system". American Journal of Agricultural Economics, 79(4): 1182-1185.

Balcombe, K. G., and Davis, J. R. (1996). "An application of cointegration theory in the estimation of the almost ideal demand system for food consumption in Bulgaria". Agricultural Economics 15(1): 47-60.

Baldwin, M. A., Hadid, M., and Phillips, G. D. A. (1983). "The estimation and testing of a system of demand equations for the UK". Applied Economics 15(1): 81-90.

Blanciforti, L. A., Green, R. D., and King, G. A. (1986). "U.S. Consumer Behavior over the Postwar Period: An Almost Ideal Demand System Analysis". Monographs, University of California, Davis, Giannini Foundation, Number 11939, December.

Blanciforti, L., and Green, R. (1983). "An almost ideal demand system incorporating habits: an analysis of expenditures on food and aggregate commodity groups". The Review of Economics and Statistics, 511-515.

Bera, A.K., Byron, R.P., and Jarque, C. M. (1981). "Further evidence on asymptotic tests for homogeneity and symmetry in large demand systems". Economics Letters 8(2): 101105.

Brown, T.M. (1952). "Habit persistence and lags in consumer behaviour". Econometrica: Journal of the Econometric Society, 355-371.

Buse, A. (1994). "Evaluating the linearized almost ideal demand system". American Journal of Agricultural Economics 76(4): 781-793.

Chambers, M.J. (1990). "Forecasting with demand systems: A comparative study". Journal of Econometrics 44(3): 363-376.

Chen, D.L. (2001). World Consumption Economics. Singapore, London: World Scientific.

Clements, K.W., Wu, Y. and Zhang, J. (2006). "Comparing international consumption patterns". Empirical Economics 31(1): 1-30.

Court, R.H. (1968). "An application of demand theory to projecting New Zealand retail consumption". The Economic Review 3: 401-11.

Deaton, A. (1974). "The analysis of consumer demand in the United Kingdom, 1900-1970". Econometrica 42: 341-61.

Deaton, A.S, and Muellbauer, J. (1980). "An Almost Ideal Demand System". American Economic Review 70: 312-326.

Deaton, A. and Case, A. (1987). "Analysis of Household Expenditures". Living Standards Measurement Study. LSMS Working Paper No. 28 Washington D.C., World Bank.

De Mello, M. M. (2001). Theoretical and empirical issues in tourism demand analysis. $\mathrm{PhD}$ Thesis, University of Nottingham, United Kingdom.

De Mello, M. M., and Fortuna, N. (2005). "Testing alternative dynamic systems for modelling tourism demand". Tourism Economics 11(4): 517-537.

Dickey, D.A., Fuller, W.A., (1979). "Distribution of the estimators for autoregressive time series with a unit root”. J. Am. Stat. Assoc. 74(366): 427-431. 
Durbarry, R., and M. T. Sinclair (2003). "Market Shares Analysis: The Case of French Tourism Demand". Annals of Tourism Research 30: 927-941.

Eakins, J. M., and Gallagher, L. A. (2003). "Dynamic almost ideal demand systems: an empirical analysis of alcohol expenditure in Ireland". Applied Economics 35(9): 10251036.

Edgerton, D. L., Assarsson, B., Hummelmose, A., Laurila, I. P., Rickertsen, K., and Vale, P. H. (1996). The Econometrics of Demand Systems: With Applications to Food Demand in the Nordic Countries. Kluwer Academic Publishers, Boston, London.

Edgerton, D. L. (1997). "Weak separability and the estimation of elasticities in multistage demand systems". American Journal of Agricultural Economics, 79(1): 62-79.

Edirisinghe, J. C. (2014). "Assessing the demand for a healthy diet in Sri Lanka: the Almost Ideal Demand System with infrequency of purchase". Economic Research, 2(2): 23-41.

Engle, R. F., and Granger, C. W. (1987). "Co-integration and error correction: representation, estimation, and testing". Econometrica: journal of the Econometric Society, 251-276.

Fanelli, L., and Mazzocchi, M. (2002). "A cointegrated VECM demand system for meat in Italy”. Applied Economics, 34(13): 1593-1605.

Hassan, Z. A., Johnson, S. R., and Green, R. (1977). "Static and dynamic demand functions; an application to the Canadian data". Publ Can Dep Agric.

Houthakker, H. S., and Taylor, L. D. (1970). Consumer Demand in the United States $\left(2^{\text {nd }}\right.$ Edition), Cambridge, Mass: Harvard University Press.

Judge, G., Griffiths, W., Cartel Hill, R., Lutkepohl, H., Lee, T., (1980). The theory and Practice of Econometrics. Wiley, New York.

Karagiannis, G., and Velentzas, K. (1993). "Habits and empirical analysis of demand for six aggregate commodity groups in Greece". Spoudai, 43: 139-54.

Karagiannis, G., and Velentzas, K. (1997). "Explaining food consumption patterns in Greece". Journal of Agricultural Economics 48(1-3): 83-92.

Karagiannis, G., Katranidis, S., and Velentzas, K. (2000). “An error correction almost ideal demand system for meat in Greece". Agricultural Economics 22(1): 29-35.

Kesavan, T., Hassan, Z. A., Jensen, H. H., and Johnson, S. R. (1993). "Dynamics and longrun structure in US meat demand". Canadian Journal of Agricultural Economics/Revue canadienne d'agroeconomie, 41(2): 139-153.

Klonaris, S., and Hallam, D. (2003). "Conditional and unconditional food demand elasticities in a dynamic multistage demand system". Applied Economics, 35(5): 503-514.

Kottage D.J.P (1988). "An Analysis of Food Consumption Expenditures of Rural Households: A Case Study of Three Regions in Sri Lanka". Unpulished Master of Economics Thesis, University of New England

Laitinen, K. (1978). "Why is demand homogeneity so often rejected?". Economics Letters, 1(3): 187-191.

Lokuge, L.D. M.N and Edirisinghe, J.C. (2015). "Econometric analysis of the demand for pulses in Sri Lanka: An Almost Ideal Estimation with a Censored Regression". Journal of Agriculture and Environment for International Development 109 (1): 41 -53.

Li, G., Song, H., and Witt, S. F. (2004). "Modelling tourism demand: A dynamic linear AIDS approach". Journal of Travel Research, 43: 141-150.

Mazzocchi, M. (2003). "Time-varying coefficients in the Almost Ideal Demand System: an empirical appraisal". European Review of Agricultural Economics, 30(2): 241-270.

Meinser, J. F. (1979). "The sad fate of the asymptotic Slutsky test for large systems". Economics Letters, 2: 231-3.

Mergos, G. J., and Donatos, G. S. (1989). "Demand for food in Greece: An almost ideal demand system analysis". Journal of Agricultural Economics, 40(2): 178-184. 
Molina, J. A. (1994). "Food demand in Spain: an application of the Almost Ideal demand system". Journal of Agricultural Economics, 45: 252-8.

Nigel, J., and Bogahawatte, C. (1990). "Demand systems of food using cross-section data: evidence from Badulla district, Sri Lanka". Tropical Agricultural Research, 2: 183-196.

Nirmali, S. A. N. and Edirisinghe, J. C. (2015). "Food demand elasticities, price changes and calorie availability of households in the Western province of Sri Lanka". Sri Lankan Journal of Agricultural Economics 12: 15-26.

Nzuma, J. M., and Sarker, R. (2010). "An error corrected almost ideal demand system for major cereals in Kenya". Agricultural Economics 41(1): 43-50.

Phillips, P. C., and Perron, P. (1988). "Testing for a unit root in time series regression". Biometrika, 75(2): 335-346.

Phlips, L. (1983). The economics of price discrimination. Cambridge University Press.

Pollak, R. A., and Wales, T. J. (1969). Estimation of the linear expenditure system.

Econometrica: Journal of the Econometric Society, 611-628.

Pradhan, J. and Tudawe, I. (1997). "Food consumption pattern in Sri Lanka: An application of the LA/AIDS model". Paper presented at the 41st Annual Conference of the Australian Agricultural and Resource Economics Society, Pan Pacific hotel, Gold Coast, Australia.

Rathnayake, I.M., Priyadarshanie, N. and Weerahewa, J. (2004). "Structural change in demand for cereals in Sri Lanka". Tropical Agricultural Research 16: 292-304.

Ray, R. (1984). "A dynamic generalisation of the almost ideal demand system". Economics Letters, 14(2-3): 235-239.

Sahn, D. E. (1988). "The effect of price and income changes on food-energy intake in Sri Lanka". Economic development and cultural Change, 36(2): 315-340.

Selvanathan, S. (1993). A System-wide Analysis of International Consumption Patterns. Advanced Studies in Theoretical and Applied Econometrics, Boston: Kluwer Academic Publishers.

Selvanathan, E.A. and Clements, K. (1995). Recent Developments in Applied Demand Analysis: Alcohol, Advertising and Global Consumption, Springer-Verlag, Berlin.

Selvanathan, E.A. and Selvanathan, S. (2003). International Consumption Comparisons: OECD versus $L D C$, World Scientific Publishing Company Private Limited, Singapore.

Selvanathan, S. and Selvanathan, E.A. (2006). "Consumption Patterns of Food, Tobacco and beverages; A Cross Country Analysis". Applied Economics 38(13): 1567-1584.

Shukur, G. (2002). "Dynamic specification and misspecification in systems of demand equations: a testing strategy for model selection". Applied Economics, 34(6): 709-725.

Singh, K., Dey, M. M., and Thapa, G. (2011). "An error corrected almost ideal demand system for crustaceans in the United States". Journal of international food \& agribusiness marketing 23(3): 271-284.

Theil, H. (1975/76). Theory and Measurement of Consumer Demand, Two volumes, North Holland Publishing Company, Amsterdam.

Tridimas, G. (2000). "The analysis of consumer demand in Greece. Model selection and dynamic specification". Economic Modelling, 17(4): 455-471.

Weerahewa, J., Rajapakse, C. and Pushpakumara, G. (2013). "An analysis of consumer demand for fruits in Sri Lanka. 1981-2010". Appetite, 60: 252-258.

Wu, D. C., Li, G., and Song, H. (2011). "Analysing tourism consumption: A dynamic system of equations approach". Journal of Travel Research, 50, 46-56.

$\mathrm{Wu}$, D. C., Li, G., and Song, H. (2012). "Economic analysis of tourism consumption dynamics: A time-varying parameter demand system approach". Annals of Tourism Research, 39(2): 667-685. 
Table 1 Classification of commodities.

\begin{tabular}{ll} 
Commodity Group & Description \\
\hline 1. Food & Food, Non-alcoholic and Alcoholic beverages \\
2. Clothing & Clothing and Footwear \\
3. Housing & Rent, Fuel and Power \\
4. Durables & Furniture, Furnishings, Household equipment and operation \\
5. Medical care & Medical care and Health expenses \\
6. Transport & Personal transport equipment and Communications \\
7. Recreation & Educational, Recreational, Entertainment and Cultural services \\
8. Miscellaneous & Personal care, Expenditure in restaurants, Cafes and Hotels and Other \\
\hline
\end{tabular}

Table 2 Budget shares of eight broad commodity groups (in percentages), Sri Lanka, 1963-2016.

\begin{tabular}{|c|c|c|c|c|c|c|c|c|c|}
\hline Commodity & $\begin{array}{l}1963 \\
(2) \\
\end{array}$ & $\begin{array}{l}1985 \\
(3) \\
\end{array}$ & $\begin{array}{l}2000 \\
(4) \\
\end{array}$ & $\begin{array}{r}2016 \\
(5) \\
\end{array}$ & Period mean & $\begin{array}{l}\text { Minimum } \\
\text { (7) }\end{array}$ & $\begin{array}{c}\text { Maximum } \\
(8) \\
\end{array}$ & $\begin{array}{c}\text { Standard } \\
\text { deviation } \\
(9)\end{array}$ & $\begin{array}{c}\text { Coefficient } \\
\text { of variation } \\
(10)\end{array}$ \\
\hline Food & 66.90 & 56.42 & 51.42 & 40.99 & 56.22 & 38.64 & 71.39 & 9.79 & 17.41 \\
\hline Clothing & 6.62 & 7.07 & 9.35 & 4.68 & 7.03 & 4.68 & 9.90 & 1.19 & 16.97 \\
\hline Housing & 7.30 & 5.90 & 7.30 & 15.38 & 7.80 & 3.94 & 15.38 & 3.38 & 43.35 \\
\hline Durables & 4.20 & 4.67 & 4.54 & 4.31 & 4.68 & 3.16 & 6.95 & 0.82 & 17.62 \\
\hline Medical care & 2.70 & 1.61 & 1.60 & 2.02 & 1.94 & 1.23 & 3.77 & 0.59 & 30.12 \\
\hline Transport & 5.48 & 16.45 & 17.12 & 25.54 & 14.73 & 5.48 & 26.94 & 6.81 & 46.21 \\
\hline Recreation & 5.81 & 4.83 & 3.14 & 2.78 & 4.01 & 2.49 & 6.89 & 1.21 & 30.10 \\
\hline Miscellaneous & 0.99 & 3.06 & 5.54 & 4.30 & 3.58 & 0.95 & 5.56 & 1.20 & 33.46 \\
\hline
\end{tabular}


Table 3 ADF test results for commodity prices and total expenditure.

\begin{tabular}{lccccc}
\hline Series & $\begin{array}{c}\text { Level series } \\
\text { Test Statistics } \\
(2)\end{array}$ & $\begin{array}{c}\text { p-value } \\
(3)\end{array}$ & $\begin{array}{c}\text { First differences } \\
\text { Test Statistics } \\
(4)\end{array}$ & $\begin{array}{c}\text { p-value } \\
(5)\end{array}$ & $\begin{array}{c}\mathrm{I}(\mathrm{d}) \\
(6)\end{array}$ \\
\hline Budget shares (w) & & & & & \\
w food & -0.347 & 0.919 & -6.739 & 0.000 & $I(1)$ \\
w clothing & -2.131 & 0.232 & -8.968 & 0.000 & $I(1)$ \\
w housing & 0.360 & 0.980 & -6.998 & 0.000 & $I(1)$ \\
w durables & -2.426 & 0.135 & -5.966 & 0.000 & $I(1)$ \\
w medical care & -2.404 & 0.141 & -6.655 & 0.000 & $I(1)$ \\
w transport & -0.333 & 0.921 & -7.169 & 0.000 & $I(1)$ \\
w recreation & -2.577 & 0.098 & -8.027 & 0.000 & $I(1)$ \\
w miscellaneous & -2.949 & $0.040 *$ & -9.710 & 0.000 & $I(1)^{*}$ \\
& & & & & \\
Logarithm of commodity prices $(\log \mathrm{p})$ & & & & & \\
Log p food & -0.330 & 0.921 & -5.214 & 0.000 & $I(1)$ \\
Log p clothing & 0.260 & 0.975 & -7.646 & 0.000 & $I(1)$ \\
Log p housing & -0.263 & 0.931 & -4.657 & 0.002 & $I(1)$ \\
Log p durables & -0.226 & 0.935 & -7.513 & 0.000 & $I(1)$ \\
Log p medical care & -0.479 & 0.896 & -6.931 & 0.000 & $I(1)$ \\
Log p transport & -0.469 & 0.898 & -6.870 & 0.000 & $I(1)$ \\
Log p recreation & -0.875 & 0.796 & -11.541 & 0.000 & $I(1)$ \\
Log p miscellaneous & -0.542 & 0.884 & -7.299 & 0.000 & $I(1)$ \\
Log of total expenditure(M) & 0.935 & 0.994 & -5.125 & 0.000 & $I(1)$ \\
Log(M/P) & 1.682 & 0.998 & -6.255 & 0.000 & $I(1)$ \\
\hline Sigifici & & & & &
\end{tabular}

*significant at $1 \%$ level. 
Table 4 Results of cointegration test.

\begin{tabular}{|c|c|c|c|c|}
\hline \multirow{2}{*}{$\begin{array}{l}\text { Series } \\
\text { (1) }\end{array}$} & \multicolumn{2}{|c|}{ Dickey-Fuller cointegration test } & \multicolumn{2}{|c|}{ Philips-Perron cointegration test } \\
\hline & $\begin{array}{c}\text { Test Statistics } \\
\text { (2) }\end{array}$ & $\begin{array}{c}\text { p-value } \\
\text { (3) }\end{array}$ & $\begin{array}{c}\text { Test Statistics } \\
\text { (4) }\end{array}$ & $\begin{array}{c}\text { p-value } \\
\text { (5) }\end{array}$ \\
\hline \multicolumn{5}{|l|}{ Budget shares (w) } \\
\hline $\mathrm{w}$ food & -5.272 & 0.000 & -5.179 & 0.000 \\
\hline w clothing & -5.742 & 0.000 & -5.949 & 0.000 \\
\hline w housing & -4.442 & 0.000 & -4.404 & 0.000 \\
\hline w durables & -3.911 & 0.002 & -3.993 & 0.001 \\
\hline w medical care & -4.321 & 0.000 & -4.294 & 0.001 \\
\hline w transport & -5.797 & 0.000 & -5.727 & 0.000 \\
\hline w recreation & -5.328 & 0.000 & -5.319 & 0.000 \\
\hline $\mathrm{w}$ miscellaneous & -5.528 & 0.000 & -5.399 & 0.000 \\
\hline
\end{tabular}

Table 5 Homogeneity and symmetry restriction tests.

\begin{tabular}{|c|c|c|c|c|c|c|c|c|c|c|c|c|}
\hline & \multicolumn{3}{|c|}{ Homogeneity } & \multicolumn{5}{|c|}{ Symmetry } & \multicolumn{4}{|c|}{ Homogeneity \& Symmetry } \\
\hline & $\begin{array}{l}\text { Calculated } \\
\text { value }\end{array}$ & Critical & value & Conclusion & $\begin{array}{c}\text { Calculated } \\
\text { value }\end{array}$ & Critical & value & Conclusion & $\begin{array}{c}\text { Calculated } \\
\text { value }\end{array}$ & Critical & value & Conclusion \\
\hline & & $1 \%$ & $5 \%$ & & & $1 \%$ & $5 \%$ & & & $1 \%$ & $5 \%$ & \\
\hline Static LA-AIDS & 4.31 & 5.86 & 3.32 & Accept* & 2.53 & 2.58 & 1.94 & Accept* & 3.90 & 2.30 & 1.79 & Reject \\
\hline Dynamic LA-AIDS & 1.96 & 5.99 & 3.38 & Accept & 1.53 & 2.72 & 2.01 & Accept & 1.14 & 2.44 & 1.87 & Accept \\
\hline EC LA-AIDS & 2.15 & 5.91 & 3.34 & Accept & 1.89 & 2.64 & 1.96 & Accept & 1.70 & 2.35 & 1.82 & Accept \\
\hline
\end{tabular}

*Accept at the $1 \%$ level. 
Table 6 Information inaccuracies $I_{i t}$ and $I_{t}\left(\times 10^{2}\right)$.

\begin{tabular}{lcccl}
\hline \multirow{2}{*}{ Commodity } & \multicolumn{3}{c}{ Demand Model } & \multirow{2}{*}{ Best-fit } \\
\cline { 2 - 4 } & Static LA-AIDS & $\begin{array}{c}\text { Dynamic } \\
\text { LA-AIDS }\end{array}$ & EC LA-AIDS & \\
\hline Food & 727.32 & 776.56 & 561.25 & EC LA-AIDS \\
Clothing & 549.30 & 367.98 & 307.95 & EC LA-AIDS \\
Housing & 661.98 & 347.63 & 394.04 & Dynamic LA-AIDS \\
Durables & 350.92 & 203.99 & 208.07 & Dynamic LA-AIDS \\
Medical care & 289.93 & 141.30 & 160.94 & Dynamic LA-AIDS \\
Transport & 355.59 & 369.69 & 308.49 & EC LA-AIDS \\
Recreation & 566.58 & 526.21 & 456.42 & EC LA-AIDS \\
Miscellaneous & 681.59 & 658.20 & 554.45 & EC LA-AIDS \\
Total $\left(I_{t}\right)$ & 4183.22 & 3391.56 & 3001.59 & EC LA-AIDS \\
\hline
\end{tabular}


Table 7 Parameter estimates of EC-LA-AIDS for eight broad commodity groups, Sri Lanka, 1963-2016.

\begin{tabular}{|c|c|c|c|c|c|c|c|c|}
\hline \multirow[t]{2}{*}{ Parameter } & \multicolumn{8}{|c|}{ Estimated Parameters } \\
\hline & Food & Clothing & Housing & Durables & Medical care & Transport & Recreation & Miscellaneous \\
\hline$\gamma_{i 1}$ & $\begin{array}{l}0.080 \\
(2.65)\end{array}$ & $\begin{array}{l}-0.020 \\
(-1.81)\end{array}$ & $\begin{array}{l}-0.021 \\
(-1.65)\end{array}$ & $\begin{array}{l}-0.016 \\
(-2.08)\end{array}$ & $\begin{array}{l}-0.015 \\
(-2.90)\end{array}$ & $\begin{array}{l}-0.008 \\
(-0.60)\end{array}$ & $\begin{array}{l}-0.002 \\
(-0.21)\end{array}$ & $\begin{array}{l}0.002 \\
(0.21)\end{array}$ \\
\hline$\gamma_{i 2}$ & $\begin{array}{l}-0.020 \\
(-1.81)\end{array}$ & $\begin{array}{l}0.012 \\
(1.42)\end{array}$ & $\begin{array}{l}0.000 \\
(0.03)\end{array}$ & $\begin{array}{l}0.003 \\
(0.64)\end{array}$ & $\begin{array}{c}0.000 \\
(-0.03)\end{array}$ & $\begin{array}{l}0.002 \\
(0.22)\end{array}$ & $\begin{array}{l}-0.001 \\
(-0.30)\end{array}$ & $\begin{array}{l}0.005 \\
(0.93)\end{array}$ \\
\hline$\gamma_{i 3}$ & $\begin{array}{l}-0.021 \\
(-1.65)\end{array}$ & $\begin{array}{l}0.000 \\
(0.03)\end{array}$ & $\begin{array}{l}0.021 \\
(2.05)\end{array}$ & $\begin{array}{l}0.024 \\
(4.44)\end{array}$ & $\begin{array}{l}-0.001 \\
(-0.26)\end{array}$ & $\begin{array}{l}-0.019 \\
(-2.46)\end{array}$ & $\begin{array}{l}0.000 \\
(0.08)\end{array}$ & $\begin{array}{l}-0.004 \\
(-0.82)\end{array}$ \\
\hline$\gamma_{i 4}$ & $\begin{array}{l}-0.016 \\
(-2.08)\end{array}$ & $\begin{array}{l}0.003 \\
(0.64)\end{array}$ & $\begin{array}{l}0.024 \\
(4.44)\end{array}$ & $\begin{array}{l}0.002 \\
(0.28)\end{array}$ & $\begin{array}{l}0.006 \\
(1.67)\end{array}$ & $\begin{array}{l}-0.013 \\
(-2.34)\end{array}$ & $\begin{array}{l}-0.002 \\
(-0.46)\end{array}$ & $\begin{array}{l}-0.004 \\
(-0.87)\end{array}$ \\
\hline$\gamma_{i 5}$ & $\begin{array}{l}-0.015 \\
(-2.90)\end{array}$ & $\begin{array}{c}0.000 \\
(-0.03)\end{array}$ & $\begin{array}{l}-0.001 \\
(-0.26)\end{array}$ & $\begin{array}{l}0.006 \\
(1.67)\end{array}$ & $\begin{array}{c}0.000 \\
(-0.10)\end{array}$ & $\begin{array}{l}-0.005 \\
(-1.44)\end{array}$ & $\begin{array}{l}0.010 \\
(4.67)\end{array}$ & $\begin{array}{l}0.005 \\
(1.82)\end{array}$ \\
\hline$\gamma_{i 6}$ & $\begin{array}{l}-0.008 \\
(-0.60)\end{array}$ & $\begin{array}{l}0.002 \\
(0.22)\end{array}$ & $\begin{array}{l}-0.019 \\
(-2.46)\end{array}$ & $\begin{array}{l}-0.013 \\
(-2.34)\end{array}$ & $\begin{array}{l}-0.005 \\
(-1.44)\end{array}$ & $\begin{array}{l}0.060 \\
(5.34)\end{array}$ & $\begin{array}{l}-0.010 \\
(-1.75)\end{array}$ & $\begin{array}{l}-0.007 \\
(-1.25)\end{array}$ \\
\hline$\gamma_{i 7}$ & $\begin{array}{l}-0.002 \\
(-0.21)\end{array}$ & $\begin{array}{l}-0.001 \\
(-0.30)\end{array}$ & $\begin{array}{l}0.000 \\
(0.08)\end{array}$ & $\begin{array}{l}-0.002 \\
(-0.46)\end{array}$ & $\begin{array}{l}0.010 \\
(4.67)\end{array}$ & $\begin{array}{l}-0.010 \\
(-1.75)\end{array}$ & $\begin{array}{l}0.009 \\
(1.65)\end{array}$ & $\begin{array}{l}-0.005 \\
(-1.22)\end{array}$ \\
\hline$\gamma_{i 8}$ & $\begin{array}{l}0.002 \\
(0.21)\end{array}$ & $\begin{array}{l}0.005 \\
(0.93)\end{array}$ & $\begin{array}{l}-0.004 \\
(-0.82)\end{array}$ & $\begin{array}{l}-0.004 \\
(-0.87)\end{array}$ & $\begin{array}{l}0.005 \\
(1.82)\end{array}$ & $\begin{array}{l}-0.007 \\
(-1.25)\end{array}$ & $\begin{array}{l}-0.005 \\
(-1.22)\end{array}$ & $\begin{array}{l}0.008 \\
(1.30)\end{array}$ \\
\hline$\beta_{i}$ & $\begin{array}{l}-0.100 \\
(-2.66)\end{array}$ & $\begin{array}{l}0.013 \\
(0.89)\end{array}$ & $\begin{array}{l}0.060 \\
(3.68)\end{array}$ & $\begin{array}{l}-0.015 \\
(-1.47)\end{array}$ & $\begin{array}{l}0.000 \\
(0.05)\end{array}$ & $\begin{array}{l}0.032 \\
(1.57)\end{array}$ & $\begin{array}{l}0.004 \\
(0.26)\end{array}$ & $\begin{array}{c}0.006 \\
(-0.42)\end{array}$ \\
\hline$\theta_{i}$ & $\begin{array}{l}0.142 \\
(3.10)\end{array}$ & $\begin{array}{l}0.142 \\
(3.10)\end{array}$ & $\begin{array}{l}0.142 \\
(3.10)\end{array}$ & $\begin{array}{l}0.142 \\
(3.10)\end{array}$ & $\begin{array}{l}0.142 \\
(3.10)\end{array}$ & $\begin{array}{l}0.142 \\
(3.10)\end{array}$ & $\begin{array}{l}0.142 \\
(3.10)\end{array}$ & $\begin{array}{l}0.142 \\
(3.10)\end{array}$ \\
\hline$\lambda_{i}$ & $\begin{array}{c}-0.632 \\
(-12.23)\end{array}$ & $\begin{array}{c}-0.632 \\
(-12.23)\end{array}$ & $\begin{array}{c}-0.632 \\
(-12.23)\end{array}$ & $\begin{array}{c}-0.632 \\
(-12.23)\end{array}$ & $\begin{array}{c}-0.632 \\
(-12.23)\end{array}$ & $\begin{array}{c}-0.632 \\
(-12.23)\end{array}$ & $\begin{array}{l}-0.632 \\
(-12.23)\end{array}$ & $\begin{array}{c}-0.632 \\
(-12.23)\end{array}$ \\
\hline
\end{tabular}

Note: $t$ statistics are in parentheses. 
Table 8 Demand elasticities for eight broad commodity groups, Sri Lanka, 1963-2016.

\begin{tabular}{lccccc}
\hline \multirow{2}{*}{ Commodity } & \multicolumn{2}{l}{ Expenditure elasticities } & & \multicolumn{2}{c}{ Own-price elasticities } \\
\cline { 2 - 3 } \cline { 5 - 6 }$(1)$ & Short-run & Long-run & & Short-run & Long-run \\
Food & $(2)$ & $(3)$ & & $(4)$ & $(5)$ \\
Clothing & 0.822 & 0.634 & & -0.758 & -0.673 \\
& $(0.067)$ & $(0.036)$ & & $(0.091)$ & $(0.079)$ \\
Housing & 1.188 & 0.858 & & -0.845 & -0.657 \\
& $(0.210)$ & $(0.133)$ & & $(0.133)$ & $(0.233)$ \\
Durables & 1.773 & 2.846 & & -0.792 & -0.885 \\
& $(0.210)$ & $(0.123)$ & & $(0.147)$ & $(0.166)$ \\
Medical care & 0.682 & 0.616 & & -0.951 & -0.645 \\
& $(0.217)$ & $(0.132)$ & & $(0.134)$ & $(0.178)$ \\
Transport & 1.015 & 1.787 & & -1.018 & -0.991 \\
& $(0.313)$ & $(0.191)$ & & $(0.185)$ & $(0.223)$ \\
Recreation & 1.214 & 1.403 & & -0.623 & -0.735 \\
& $(0.136)$ & $(0.065)$ & & $(0.097)$ & $(0.123)$ \\
Miscellaneous & 1.098 & 1.399 & & -0.786 & -0.730 \\
& $(0.370)$ & $(0.184)$ & $(0.147)$ & $(0.162)$ \\
& 1.161 & 0.975 & -0.786 & -0.613 \\
Note: Stand & $(0.388)$ & $(0.192)$ & $(0.183)$ & $(0.268)$ \\
\hline
\end{tabular}

Note: Standard errors are in parentheses. 
- This paper models the dynamic behaviour of consumption patterns using annual time series data for eight commodity groups using a static and two dynamic versions of AIDS, namely Linear Approximated AIDS (LA-AIDS), Dynamic Linear Approximated AIDS (Dynamic LA-AIDS), and Error Corrected Linear Approximated AIDS (EC LA-AIDS).

- Results suggest that both dynamic LA-AIDs and EC LA-AIDS satisfy the demand theory hypotheses and perform better than the static LA-AIDS.

- Both the short and long run own-price elasticities for all commodities are negative, and all the commodities have price inelastic demand in both time horizons.

- Housing, medical care, and recreation are found to be luxuries for Sri Lankan consumers, both in the short and long run. However, clothing is a necessity in the long run, while it is a luxury in the short run.

- With regard to Sri Lanka, consumers are more sensitive to price and income changes in the long run than in the short run in consuming most of the commodities.

- The deviation between the short-run and the long-run demand elasticities show the need for adopting a dynamic approach in estimating demand elasticities which can be used for policy and welfare analyses.

- This study identifies the appropriate dynamic structure to represent the data while investigating the empirical validity of the constraints of homogeneity and symmetry.

- This study is able to provide a new insights into the analysis of Sri Lankan consumption patterns while providing more reliable information for policy evaluation than the static demand models.

- The income and price elasticities obtained from this study can be used as key inputs in computations of optimal taxation, tax reforms and in applied computable general equilibrium models. 